\title{
General Principles of EU Law
}

\author{
Armin Cuyvers
}

\subsection{Legal Dark Matter}

In certain ways, general principles can be understood as the dark matter of EU law. They unify the law, fill gaps, and lend weight and legitimacy to the EU legal order as a whole. Like dark matter, moreover, legal principles can be hard to pin down and describe, as often it is their flexibility and fluidity that allows them to successfully fulfil the different role they play. Principles are also intimately connected to values, often giving a legal voice to considerations of morality and social convictions that cannot enter the legal plane directly. ${ }^{1}$ Because of their flexibility, general principles may also enable a legal order to evolve and adapt, as the general principles themselves may develop along new realities and responsibilities, but they may also be used to re-interpret rules that block progress.

This Chapter briefly discusses the general principles of EU law. Because the EU legal order knows a great many general principles, and because these principles play many roles, it is impossible to provide anything close to a complete overview here. ${ }^{2}$ Instead, taking into account the comparative aim of this book and the limited space available, this Chapter focusses on one issue that may be of particular importance for the EAC: the protection of fundamental rights as general principles of EU law. Several other important principles of EU law including direct effect, supremacy, subsidiarity and proportionality, are discussed in other EU Chapters. ${ }^{3}$

1 See for example R. Dworkin, 'Taking Rights Seriously' (Duckworth, 1977), Chapters 1 and 2 and (for a different approach) J. Raz, 'Legal Principles and the Limits of Law', 81 Yale Law Journal 823 .

2 For two impressive volumes dedicated to General Principles in EU law, which can provide a fuller if still not even complete overview, see T. Tridimas, The General Principles of EU Law (2nd edn, OUP, 2006) and X. Groussot, General Principles of Community Law (Europa Law Publishing, 2006).

3 See EU Chapters 2, 3, and 4 for the principles of supremacy, direct effect, conferral and subsidiarity. See the EU Chapters on the internal market and free movement for the application of the principle of proportionality and consistency. 
Before we engage with the issue of fundamental rights, the next section first provides an overview of the nature, legal basis and functions of general principles in the $\mathrm{E} U$ legal order.

\subsection{General Principles in the EU Legal Order}

Unlike the EAC, many general principles of EU law are unwritten and judgemade, even though over time many have been codified in the Treaty. ${ }^{4}$ Many of the more institutional-type of principles can now be found in the beginning of the TEU, such as the principle of sincere cooperation, conferral, Member State equality and the respect for national constitutional identity, subsidiarity, and proportionality. ${ }^{5}$ Article 6 TEU, which was only introduced with the 1992 Treaty of Maastricht, now forms the central Treaty provision for the more substantive general principles relating to fundamental rights:

1. The Union recognises the rights, freedoms and principles set out in the Charter of Fundamental Rights of the European Union of 7 December 2000, as adapted at Strasbourg, on 12 December 2007, which shall have the same legal value as the Treaties.

(...)

2. The Union shall accede to the European Convention for the Protection of Human Rights and Fundamental Freedoms. Such accession shall not affect the Union's competences as defined in the Treaties.

3. Fundamental rights, as guaranteed by the European Convention for the Protection of Human Rights and Fundamental Freedoms and as they result from the constitutional traditions common to the Member States, shall constitute general principles of the Union's law.

Some other provisions, moreover, contain important principles of non-discrimination, including Articles 18, 45 and 157 TFEU. Several important principles of Eu law, however, still have no Treaty basis and remain based on the case

4 See on the different categories and types of general principles also A. von Bogdandy, 'Founding Principles' in: A. von Bogdandy and J. Bast (eds), Principles of European Constitutional Law (2nd edn., Hart, 2010), 11.

5 See Articles 4 and 5 TEU. 
law of the CJEU. These unwritten principles include direct effect, supremacy and effectiveness, three of the most distinctive principles of Eu law. ${ }^{6}$

In terms of hierarchical status, the general principles are usually considered part of primary law (certainly when they are codified in the Treaty), or otherwise as a special category of norms that are just below primary law but above all other EU law, including secondary legislation and international agreements signed by the EU. The hierarchical status of general principles is important for the question if principles can even trump the Treaties themselves, and thereby the will of the Member States as 'Masters of the Treaty'. The orthodox position still is that this is not possible, although some recent case law may suggest that there are some core principles that may in some cases acquire a supra-Treaty status. ${ }^{7}$

One of the reasons that $\mathrm{E} U$ law has so many general principles, and that these principles play such an important role, is that on many points the Treaties only lay down a very limited and open framework. As we shall see moreover, this limited framework was primarily focussed on economic integration, and less on other legal issues such as fundamental rights. Consequently, it was often up to the CJEU to fill in the general framework, provide protection where necessary, and generally breathe life into the bare bones of the Treaties.

This background of general principles can also be seen in the different functions general principles fulfil in the $\mathrm{E} U$ legal order. Although alternative categorizations are possible, one can say principles play at least four key roles. Firstly, general principles can form an aid to interpretation of primary or secondary law. ${ }^{8}$ Secondly, because of their hierarchical status, general principles can be used to review the legality of secondary Eu law and international agreements

6 The CJEU has also accepted multiple other, less far reaching principles in its case law, such as the principle of legal certainty, legitimate expectations or national procedural autonomy. See for example CJEU Case 112/77 Töpfer, Case C-453/oo Kühne \& Heitz [2004] ECR I-837or Case C-234/04 Kapferer [2006] ECR I-2585. For an example of a principle that was rejected, however, see Case C-189/01 Jippes ECLI:EU:C:2001:420 on animal welfare. See on direct effect and supremacy also Eu Chapter 4.

7 See especially Case C-402/05 P Kadi [2008] ECRI-6351, to which we will return below. See for the claim that these principle can trump primary law for example A. Rosas and L. Armati, $E U$ Constitutional Law (Hart, 2010), pp. 38-39. For further discussion see. Idriz-Tescan, Legal constraints on EU Member States as primary law makers: a case study of the proposed permanent safeguard clause on free movement of persons in the EU negotiating framework for Turkey's accession (Diss. Leiden 2015, Meijersreeks; MI-247) and A. Cuyvers, 'The Kadi II judgment of the General Court: the ECJ's predicament and the consequences for Member States'. 7 (2011) European Constitutional Law Review,. 481.

8 See for a far reaching and contested example Case C-402/o7 Sturgeon ECLI:EU:C:2009:716. 
signed by the EU. ${ }^{9}$ Third, general principles form an independent basis for Member State liability. ${ }^{10}$ Fourth, general principles can be used as 'gap fillers'. Where there is no relevant $\mathrm{EU}$ law, or the relevant rules simply do not provide an answer, general principles may be used to fill the gap in EU law in a way that is consistent with the overall body of EU law and the general principles. ${ }^{11}$

As indicated, the remainder of this Chapter focusses on two further topics that may be of particular interest to the EAC, starting with the pervasive, if not always visible, principle of effectiveness.

\subsection{Fundamental Rights and General Principles in the EU}

Like the EACJ, the CJEU does not have a separate fundamental rights jurisdiction. In other words, individuals cannot go to the CJEU, or even rely on EU law, just because one of their fundamental rights may have been violated. Individuals and companies can only rely on any rights granted by Eu law when they are under the scope of EU law, for example because they have moved to another Member State, or because they fall under a piece of $\mathrm{E} U$ legislation.

Even though EU law today contains multiple fundamental rights, including a complete EU Charter of Fundamental Rights, these rights themselves, therefore, do not bring an individual within the scope of EU law or create jurisdiction for the CJEU, as will be explained in more detail below. Nevertheless, the EU has developed an effective protection of fundamental rights within the scope or EU law, largely through the creation and application of general principles. This is quite an achievement if one considers that, in the beginning of European integration, the Treaties did not refer to fundamental rights at all, and the CJEU even explicitly refused to apply fundamental rights.

This section therefore outlines how the CJEU used general principles to go from a situation in which EU law offered no protection of fundamental rights to a situation where the EU legal order identifies itself as a bastion of fundamental rights protection.

9 Joined Cases C-293 and 594/12 Data Retention Directive ECLI:EU:C:2014:238.

10 Case C-6/9o and 9/9o Francovich [1991] ECR I-5357 and Case C-46 and 48/93 Brasserie $d u$ Pêcheur [1996] ECR I-1029.

11 See for example Case C-555/07 Kücükdeveci [2010] ECR I-365 or Case 294/83 Les Verts ECR 1986 p. 1339. 


\subsubsection{Genesis of Fundamental Rights in the EU}

The evolution of fundamental rights in the EU starts with their firm denial by the CJEU in Stork. ${ }^{12}$ A German company wanted to rely on several fundamental rights contained in the German constitution against a secondary act of EU law. In its reply, the CJEU emphasized the economic nature of the Community:

under Article 8 of the Treaty the High Authority is only required to apply Community law. It is not competent to apply the national law of the Member States. Similarly, under Article 31 the Court is only required to ensure that in the interpretation and application of the Treaty ... the law is observed. It is not normally required to rule on provisions of national law. Consequently, the High Authority is not empowered to examine a ground of complaint which maintains that, when it adopted its decision, it infringed principles of German constitutional law (in particular Articles 2 and 12 of the Basic Law).

The denial to protect fundamental rights, however, led to increasing concern at the national level. Especially some national constitutional courts were alarmed by a Community that claimed increasing authority, including supremacy over national law, but did not offer fundamental rights protection. This concern was one of the reasons behind the landmark judgment in Solange I by the German Constitutional Court (GCC). The GCC held that as long as fundamental rights were not adequately protected in the Community legal order, it reserved the right to disapply Community law in Germany. ${ }^{13}$

Faced with the understandable claim that an increasingly powerful EU should protect fundamental rights, the CJEU changed course. In Internationale Handelsgesellschaft and Nold the CJEU suddenly 'discovered' that Eu law actually did contain fundamental rights in the form of general principles. ${ }^{14}$ in Internationale Handelsgesellschaft, for example, the cJEu held that:

However, an examination should be made as to whether or not any analogous guarantee inherent in Community law has been disregarded. In fact, respect for fundamental rights forms an integral part of the general principles of law protected by the court of justice.

\footnotetext{
12 Case $1 / 58$ Stork ECR 1959 p. 17.

13 BVerfGE 37, 271 (1974) Solange I. See also EU Chapter 4 on the importance of this case law for the debate on supremacy of Eu law as such.

14 Case 11/70 Internationale Handelsgesellschaft [1970] ECR 1125 and Case C-4/73 Nold ECLI:EU:C:1974:51.
} 


\section{$(\ldots)$}

The protection of such rights, whilst inspired by the constitutional traditions common to the Member States, must be ensured within the framework of the structure and objectives of the Community. It must therefore be ascertained, in the light of the doubts expressed by the Verwaltungsgericht, whether the system of deposits has infringed rights of a fundamental nature, respect for which must be ensured in the Community. ${ }^{15}$

Similarly, in Nold the cJEU found:

As the court has already stated, fundamental rights form an integral part of the general principles of law, the observance of which it ensures. In safeguarding these rights, the court is bound to draw inspiration from constitutional traditions common to the Member States, and it cannot therefore uphold measures which are incompatible with fundamental rights recognized and protected by the constitutions of those states. Similarly, international treaties for the protection of human rights on which the member states have collaborated or of which they are signatories, can supply guidelines which should be followed within the framework of Community law. ${ }^{16}$

The CJEU, therefore, still refused to directly apply national fundamental or constitutional rights, also because doing so might threaten the autonomy and supremacy of EU law. At the same time, it used the open category of unwritten principles of EU law to create an 'analogous' protection at the EU level. The message to the national courts therefore was, do not worry, you do not need to apply your national constitutional rights, as EU law provides similar protection. In Nold, moreover, the CJEU further clarified that it would also take international treaties for the protection of human rights into account when determining the fundamental rights protection offered by the general principles of EU law.

\subsubsection{Consolidation of Fundamental Rights in the EU Legal Order}

Once the principled decision had been taken that the EU legal order protected fundamental rights, the CJEU could further develop and consolidate this protection. This consolidation was also supported by national supreme courts

15 Case 11/70 Internationale Handelsgesellschaft [1970] ECR 1125, par. 4 a.o.

16 Case C-4/73 Nold ECLI:Eu:C:1974:51, par. 13. 
responding positively to the Internationale Handelsgesellschaft and Nold line of case law. The German Constitutional Court, for example, showed its good will by retreating from its Solange I position to a more deferential approach in Solange II. ${ }^{17}$ As long as fundamental rights would be adequately protected by the CJEU, the GCC would not exercise its right to disapply Community law in Germany, although it retained the authority to do so where manifest breaches of fundamental rights would occur.

An important step in the consolidation of fundamental rights as general principles came in Baustahlgewebe. ${ }^{18}$ In this judgment the CJEU loyally applied the ECHR and the case law of the European Court of Fundamental Rights in Strasbourg (ECtHR), even though the EU was not, and is not, a party to the ECHR. This confirmed the trend of the CJEU de facto respecting the ECHR as applied by the Strasbourg court. In addition, Baustahlgewebe was the first case where the CJEU actually found a violation of a fundamental right by an EU institution. The following paragraphs of the judgment show the transformation of Article 6 ECHR into a general principle of EU law, which could then be applied by the CJEU:

It should be noted that Article 6(1) of the EHRC provides that in the determination of his civil rights and obligations or of any criminal charge against him, everyone is entitled to a fair and public hearing within a reasonable time by an independent and impartial tribunal established by law.

The general principle of Community law that everyone is entitled to fair legal process, which is inspired by those fundamental rights(...), and in particular the right to legal process within a reasonable period, is applicable in the context of proceedings brought against a Commission decision $(\ldots) \cdot{ }^{19}$

Even though the ECHR or national constitutional rights did not apply directly into the EU legal order, therefore, general principles could be used to 'import' them and transform them into principles that could be applied in the Eu legal order.

The recognition of fundamental rights in the Eu legal order, and the special significance of the ECHR in this regard, was further consolidated by the 1992 Treaty of Maastricht, which introduced the provision that has now become

\footnotetext{
17 BVerfGE 73, 339 (1986) Solange II.

18 Case C-185/95 P Baustahlgewebe ECLI:EU:C:1998:608.

19 Case C-185/95 P Baustahlgewebe ECLI:EU:C:1998:608, paras. 20-21.
} 
Article 6(3) TEU. As a result of this provision, fundamental rights as general principles, as well as the relevance of the ECHR, received a direct foundation in the Treaty, further cementing their standing and authority. ${ }^{20}$

\subsubsection{The Ascension of Fundamental Rights: The Charter and Kadi}

Despite the de facto application of the ECHR through general principles and their recognition in the Treaty, worries remained that the protection of fundamental rights within the EU might not go far enough, also because the ECHR only provides a minimum level of protection. For this reason, an EU Charter of fundamental rights was drafted, containing both the traditional fundamental rights and some more modern and social rights and 'principles'.

The Charter was first only 'solemnly proclaimed' on 7 December 2007 at the Nice European Council. Consequently, it did not have formal legal binding effect. Rather, it could be used as a tool for the EU to create or interpret the EU general principles that were legally binding. Subsequently, however, the Charter eventually became legally binding after the entry into force of the Lisbon Treaty on 1 December 2009. Somewhat embarrassingly, it was not considered politically opportune to include the Charter into the Treaties directly, this after the debacle of the Constitutional Treaty. ${ }^{21}$ Instead, Article 6(1) TEU only refers to the Charter, and declares that it has the same legal value as the Treaty. Consequently, the Charter is now part of Eu Primary law, and one of the central sources governing fundamental rights in the EU. This also means that since Lisbon, fundamental rights are both protected under the Charter and under the General principles of EU law, which continue to apply. ${ }^{22}$

20 At the same time, however, it was the same CJEU that blocked the accession of the EU to the ECHR. It was argued that the importation of ECHR rights by the CJEU carried the risk that the CJEU might, knowingly or unknowingly, get it wrong at some point, and that therefore the EU itself should also accede to the ECHR. The CJEU, however, argued that there was no sufficient legal basis for accession in Opinion 2/94 Accession by the Community to the European Convention for the Protection of Human Rights and Fundamental Freedoms ECLI:EU:C:1996:140. After this legal basis was created with the Treaty of Lisbon, however, the CJEU again blocked accession, inter alia because it might undermine the autonomy of EU law. See Opinion 2/13 on the draft agreement providing for the accession of the European Union to the Convention for the Protection of Human Rights and Fundamental Freedoms ECLI:EU:C:2014:2454.

21 See Eu Chapter 1.

22 See however, section 3.4. below on the scope of the Charter, which is identical to those of the general principles and does not create a general human rights jurisdiction for the CJEU. 
In addition to the introduction of the Charter, however, recent years saw another increase in the importance and standing of fundamental rights and general principles in the Eu legal order. The key example of this development is the Kadi saga. The Kadi cases concerned the imposition of sanctions on individuals suspected of supporting terrorism. On 17 October 2001 Kadi, a Saudi national, was placed on a UN sanctions list because he was suspected of supporting Al Qaeda. This UN sanction was based on resolutions of the Security Council under Title VII of the UN charter, and hence claimed absolute primacy over all other international law. ${ }^{23}$ The EU automatically took over all UN sanctions, so on 19 October 2001 Kadi was added to the EU sanctions list. As of that moment, all his European assets were frozen. Kadi challenged his EU sanction before the CJEU, arguing inter alia that his fundamental rights to a fair trial and an effective remedy had been violated. Consequently, the Kadi case lead to a direct conflict between $\mathrm{EU}$ fundamental rights and a resolution of the UN Security Council under Chapter viI.

The General Court essentially found that, under Article 103 UN Charter, the UN resolution trumped EU law, unless norms of jus cogens had been violated. ${ }^{24}$ The CJEU, however, took the opposite approach. It stressed the foundational importance of fundamental rights for the EU legal order, holding inter alia:

Art. 307 EC may in no circumstances permit any challenges to the principles that form part of the very foundations of the Community legal order $(\ldots) \cdot{ }^{25}$

Kadi does not yet form a sufficient basis for the conclusion that some general principles may now trump EU primary law. At the same time, it is a striking example of just how far fundamental rights and general principles have come in the Eu legal order since the initial denial of the CJEU in Stork to apply fundamental rights at all. At the same time, the impressive rise of fundamental rights

23 See amongst others Resolution 1904 (2009) and the earlier resolutions mentioned therein, as well as Article 103 of the UN Charter.

24 T-315/01 Kadi I [2005] ECR II-3649.

25 ECJ, Case C-402/05 P Kadi [2008] ECRI-6351, par. 304. See for multiple other confirmations of the fundamental importance and hierarchical standing of fundamental rights in the EU legal order also paras. $282-326 \mathrm{ECJ}$. This position was confirmed in Joined Cases C-584/10 P, C-593/10 P and C-595/10 P Kadi II, ECLI:Eu:C:2013:518. See also A. Cuyvers, "Give me one good reason": The unified standard of review for sanctions after Kadi II', 51(6) Common Market Law Review (2014), 1759. 
should not be confused with the creation of a general fundamental rights jurisdiction, as EU fundamental rights only apply within the scope of EU law.

\subsection{Protection within the Scope of EU Law Alone}

By its very nature, EU law only applies in situations that fall under the scope of EU law. ${ }^{26}$ Most importantly, this means that purely internal situation, i.e. situations that wholly take place in one Member State without any connection to EU law, do not fall under EU law. ${ }^{27}$ In such purely internal situations, EU law does not apply, and hence individuals cannot derive any protection from it. For example, if an Austrian police man were to torture an Austrian citizen in Austria, the case would likely not have any connection to EU law. Consequently, the Austrian citizen could not rely on Article 4 of the Eu Charter or on the General Principle of EU law that, inspired by Article 3 ECHR, prohibits torture. Naturally, the Austrian citizen will have the protection of the Austrian constitution, as well as the ECHR directly as Austria, as all EU Member States, is a party to the ECHR.

When drafting the Charter, the Member States wanted to make it very clear that the Charter does not extend the scope of Eu law, and most certainly does not create a general jurisdiction for fundamental rights violations. As Article 51 of the Charter is at pain to stress:

1. The provisions of this Charter are addressed to the institutions, bodies, offices and agencies of the Union with due regard for the principle of subsidiarity and to the Member States only when they are implementing Union law. They shall therefore respect the rights, observe the principles and promote the application thereof in accordance with their respective powers and respecting the limits of the powers of the Union as conferred on it in the Treaties.

2. The Charter does not extend the field of application of Union law beyond the powers of the Union or establish any new power or task for the Union, or modify powers and tasks as defined in the Treaties.'

26 See also Eu Chapter 4 par. 2 on the concept of scope.

27 Naturally, all acts by EU institutions or bodies fall under the scope of EU law, and hence under the scope of the Charter as well. Cf also Article $5^{1}(1)$ of the EU Charter. 
Despite the fact that Article 51(1) of the Charter only refers to Member States when 'implementing' Union law, the CJEU has held in Åkerberg Fransson that the scope of the Charter is the same as the scope of EU law as such:

Since the fundamental rights guaranteed by the Charter must therefore be complied with where national legislation falls within the scope of European Union law, situations cannot exist which are covered in that way by European Union law without those fundamental rights being applicable. The applicability of European Union law entails applicability of the fundamental rights guaranteed by the Charter.

Where, on the other hand, a legal situation does not come within the scope of European Union law, the Court does not have jurisdiction to rule on it and any provisions of the Charter relied upon cannot, of themselves, form the basis for such jurisdiction. ${ }^{28}$

Over time, the CJEU has clarified that there are three ways of bringing an action by a Member State situation under the scope of Eu law, and hence the Charter. Firstly, Member State actions fall under the scope of Eu law where the Member State is implementing EU law, for example by implementing a directive. Where an individual, for example, is affected by a national law that directly or indirectly implements a directive, she is under the scope of EU law, and hence can also rely on EU fundamental rights. ${ }^{29}$ Secondly, Member States fall under the scope of Eu law where they are derogating from any rule of EU law. For example, any national law that restricts a free movement right, even if it is justified, falls under the scope of Eu law. ${ }^{30}$ Lastly, and most complexly, the actions of a Member State may also 'generically' fall under Eu law. For example, this can be the case where the subject matter at stake is covered by an EU directive, even if the directive itself does not directly apply. ${ }^{31}$

28 Case C-617/10 Åkerberg Fransson ECLI:Eu:C:2013:105, paras. 20-21.

29 See for the broad concept applied by the CJEU, which does not just cover national acts that directly implement a directive, also Case C-617/10 Åkerberg Fransson ECLI:EU:C:2013:105, paras. 27-28.

$30 \quad$ See in this context also Case C-112/oo Schmidberger [2003] ECR I-5659.

31 See for example Case C-555/07 Kücükdeveci ECR I-365, where the dispute was brought under the scope of Eu law based on the directive which did not apply horizontally. Once the dispute had been brought under the scope of EU law in this creative manner, the CJEU could apply a general principle of EU law to it. For another creative extension to the scope of EU law see Case C-34/og Zambrano [2011] ECR I-1177. 
EU fundamental rights, therefore, have no general application, and the CJEU has no general fundamental rights jurisdiction. Despite these limitations, however, the protection offered by EU fundamental rights was seriously developed and improved by first developing substantive EU rights, both as general principles and via the Treaties, and secondly, by expanding the scope of EU law as such. 